\title{
Growth and Flowering Behaviour of Dendrobium Cultivars
}

\author{
H. Mehraj ${ }^{1}$, K. J. Shikha ${ }^{2}$, A. Nusrat ${ }^{1}$, I. H. Shiam ${ }^{1}$ and A. F. M. Jamal Uddin ${ }^{1 *}$ \\ Dept. of Horticulture, Sher-e-Bangla Agricultural University ${ }^{1}$ \\ International University of Business Agriculture Technology, Dhaka, Bangladesh ${ }^{2}$
}

Corresponding author*: jamal4@yahoo.com

\begin{abstract}
An experiment was conducted to evaluate growth and flowering behavior of three dendrobium cultivars coded from $V_{1}$ to $V_{3}$ (Sonia-17, Purple Boutonniere and Emma White respectively). Longest pseudobulb $(78.9 \mathrm{~cm})$ and maximum girth of pseudobulb $(19.7 \mathrm{~mm})$ was found with Sionia-17 cultivar. For the same cultivar, maximum other growth and flowering characteristics were observed and recorded as number of pseudobulb/plant (18.8), number of leaves/pseudobulb (5.3), leaf area (253.3 $\left.\mathrm{cm}^{2}\right)$, number of spikes/plant (14.9), spike length (44.6 $\mathrm{cm})$, spike girth $(7.4 \mathrm{~mm})$, number of florets/spike (12.2), diameter of bud $(26.1 \mathrm{~mm})$ and diameter of floret $(9.5 \mathrm{~cm})$. Minimum chlorophyll content (58.8\%) was also found from cultivar Sonia-17 $\left(V_{l}\right)$.
\end{abstract}

Key words: Dendrobium cultivars, growth and flowering

\section{Introduction}

Dendrobium orchid is long-lasting and colorful cut flowers. The genus Dendrobium is the third largest in the family Orchidaceae, comprising 1184 species worldwide (Leitch et al., 2009). Dendrobium genus has been produced in order to incorporate new color options for ornamental plants (Lavarack et al., 2006). Dendrobium plants are among the most prevalent orchids for commercial production of cut flowers and potted plants (Chen and Tsi, 2000) and most popular genus in horticultural industries. The genetic diversity of the Dendrobium genus is not well known (Wang et al., 2009). Comparative study of different cultivars were also conducted previously in dendrobium (Sunil and Swati, 2013; Ramachandrudu, 2008) gerbera (Ahlawat et al., 2012; Shruti and Gajbhiye, 2012), gladiolus (Shaukat et al., 2013), anthurium (Islam et al., 2013; Rajeevan et al., 2007), carnation (Singh et al., 2013). Research work on the evaluation of dendrobium cultivars for suitability to our condition is very limited. So, this study was aimed to identify the suitable varieties for growth and flowering of three available dendrobium cultivars.

\section{Materials and Method}

Experimental site and duration: An experiment was conducted at $2 a$ Rooftop garden, Department of Horticulture, Sher-e-Bangla Agricultural University, Dhaka, Bangladesh during February 2013 to August 2013.

Experimental design, genetic materials and fertilization: The experiment was laid out in Completely Randomized Design with three replications. Same aged plantlets were used in the experiment. Three cultivars viz. $\mathrm{V}_{1}$; Sonia-17, $\mathrm{V}_{2}$ : Purple Boutonniere and $\mathrm{V}_{3}$; Emma White were used in the experiment. Nitrogen, phosphorus and potassium @ 1:1:1 ratio was sprayed at the entire period of the experiment. 
Data collection and measuring procedures: Data were collected on different growth and flowering attributes. Among these attributes, length of pseudobulb, girth of pseudobulb, number of leaves/pseudobulb, leaf area and chlorophyll content were measured at 120 days after transplanting. Leaf area was measured by non-destructive method using CL-202 Leaf Area Meter (USA). SPAD502 Chlorophyll Meter was used for measuring chlorophyll content (\%). Girth of pseudobulb, girth of spike and diameter of flower bud were measured by using Digital Caliper-515 (DC-515).

Statistical analysis: Collected data were statistically analyzed by using MSTAT-C program. Mean for all cultivars was calculated and difference between cultivars was evaluated by Least Significant Difference (LSD) at 5\% level of significance (Gomez and Gomez 1984).

\section{Results and discussion}

\section{Length of pseudobulb}

Length of pseudobulb varied significantly between dendrobium cultivars. Longest pseudobulb was found from $\mathrm{V}_{1}(78.9 \mathrm{~cm})$ while shortest from $\mathrm{V}_{3}(45.7 \mathrm{~cm})$ (Table 1). Length of pseudobulb of Sonia17 was $54.57 \mathrm{~cm}$ and Emma red was $46.27 \mathrm{~cm}$ (Sugapriya et al., 2012). Variation in length of pseudobulb among cultivars is mainly due to genetic nature. Similar variation among monopodial orchid Dendrobium was also found by Roychowdhury et al. (2004) and Thomas and Lekha Rani (2008).

\section{Girth of pseudobulb}

Maximum girth of the pseudobulb was found from $\mathrm{V}_{1}(19.7 \mathrm{~mm})$ which was statistically similar with $\mathrm{V}_{2}(18.5 \mathrm{~mm})$ whereas minimum from $\mathrm{V}_{3}(15.4 \mathrm{~mm}$ ) (Table 1). Sugapriya et al. (2012) found the variation in girth of pseudobulb among Dendrobium varieties.

\section{Number of pseudobulbs/plant}

Maximum number of pseudobulb was found from $V_{1}$ (18.8) while minimum from $V_{3}$ (13.0) which was statistically similar with $V_{2}$ (14.2) (Table 1). Sugapriya et al. (2012) found the variation in number of pseudobulb/plant among the Dendrobium varieties and ranged from 3.90 to 17.0/plant. Number of pseudobulb/plant was varied due to the variation of cultivars as reported by Talia et al. (1999) and Thomas and Lekha rani (2008).

\section{Number of leaves/pseudobulb}

Maximum number of leaves/pseudobulb was found from $\mathrm{V}_{1}$ (5.3) while minimum from $\mathrm{V}_{3}(2.6)$ which was statistically similar with $\mathrm{V}_{2}$ (3.2) (Table 1). Sugapriya et al. (2012) found the variation in number of leaves/pseudobulb among the Dendrobium cultivars.

Table 1. Response of dendrobium cultivars to different growth characters ${ }^{\mathrm{x}}$

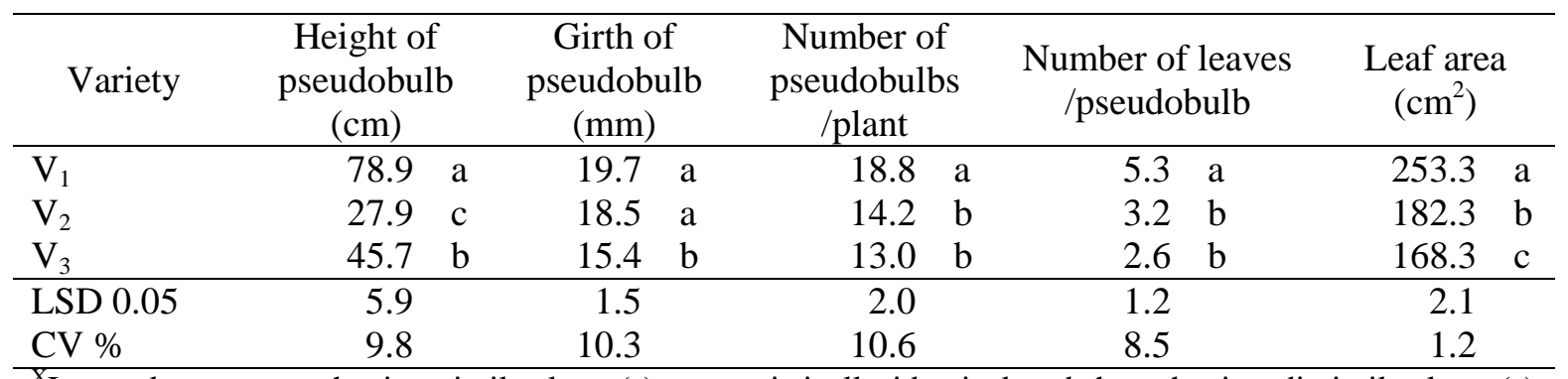

${ }^{\mathrm{X}}$ In a column means having similar letter(s) are statistically identical and those having dissimilar letter(s) differ significantly as per 0.05 level of probability 


\section{Leaf area}

Leaf area of the dendrobium cultivars varied significantly. Maximum leaf area was found from $\mathrm{V}_{1}$ $\left(253.3 \mathrm{~cm}^{2}\right)$ followed by $\mathrm{V}_{2}\left(182.3 \mathrm{~cm}^{2}\right)$ while minimum from $\mathrm{V}_{3}\left(168.3 \mathrm{~cm}^{2}\right)$ (Table 1). The results are in agreement with the findings of Nair et al. (2002) and Bhattacharjee (1981). Sugapriya et al. (2012) were also found the variation in leaf area among the Dendrobium varieties.

\section{Chlorophyll content}

Chlorophyll content of dendrobium cultivars varied significantly. Maximum chlorophyll content was found from $\mathrm{V}_{2}(71.2 \%)$ which was statistically similar with $\mathrm{V}_{3}(70.5 \%)$ whereas minimum from $\mathrm{V}_{1}$ (58.8\%) (Table 2). Maximum chlorophyll $80.53 \%$ and minimum $58.90 \%$ was found from the varietals evaluation of Dendrobium orchid (Sugapriya et al., 2012) that is similar to current study. Variation in chlorophyll content of leaf among the varieties might be attributed to the genetic constitution. Similar variation in chlorophyll content among varieties was also observed by Shiragur et al. (2004).

\section{Days to $1^{\text {st }}$ flower bud initiation}

Early flower bud initiation was observed from $\mathrm{V}_{1}$ (125.8 days) which was statistically similar with $\mathrm{V}_{2}$ (130.4 days) while late was found from $\mathrm{V}_{3}$ (154.6 days) (Table 2). Earliness in flowering (96 days) was found from cv. Sonia-17 (Sunil and Swati, 2013).

\section{Days to $1^{\text {st }}$ flower opening}

Early flower opening was found from $\mathrm{V}_{1}$ (16.0 days) which was statistically similar with $\mathrm{V}_{3}(16.4$ days) and $\mathrm{V}_{2}$ (17.3 days) (Table 2).

\section{Number of spike/plant}

Significant variation was found from the dendrobium cultivars on number of spikes/plant. Maximum number of spikes/plant was found from $V_{1}$ (14.9) while minimum from $\mathrm{V}_{3}$ (11.5) which was statistically similar with $\mathrm{V}_{2}$ (12.7) (Table 2). Sugapriya et al. (2012) reported that number of spike/plant was varied due to the variation of varieties of Dendrobium orchid. The increased flower yield might be attributed to the greater leaf area; more number of pseudobulbs per plant, more number of leaves per plant as well as leaf chlorophyll content and these would have resulted in production and accumulation of maximum photosynthates which ultimately results in production of more number of spikes with bigger sized flowers. Similarly variation also observed among the varieties by Barman et al. (2007) in Cymbidium and Thomas and Lekha rani (2008) in monopodial orchids.

Table 2. Response of dendrobium cultivars on chlorophyll content, $1^{\text {st }}$ flower bud initiation, flower opening and number of spike ${ }^{\mathrm{X}}$

\begin{tabular}{|c|c|c|c|c|}
\hline Variety & $\begin{array}{l}\text { Chlorophyll } \\
\text { content }(\%)\end{array}$ & $\begin{array}{c}\text { Days to } 1^{\text {st }} \text { flower bud } \\
\text { initiation }\end{array}$ & $\begin{array}{l}\text { Days to } 1^{\text {st }} \text { flower } \\
\text { opening }\end{array}$ & $\begin{array}{l}\text { Number of } \\
\text { spike/plant }\end{array}$ \\
\hline $\mathrm{V}_{1}$ & $58.8 \quad \mathrm{~b}$ & $125.8 \mathrm{~b}$ & 16.0 & 14.9 \\
\hline $\mathrm{V}_{2}$ & $71.2 \quad \mathrm{a}$ & $130.4 \mathrm{~b}$ & 17.3 & 12.7 \\
\hline$V_{3}$ & $70.5 \quad \mathrm{a}$ & $154.6 \mathrm{a}$ & 16.4 & 11.5 \\
\hline LSD0.05 & 2.7 & 6.7 & 1.3 & 1.9 \\
\hline $\mathrm{CV} \%$ & 4.9 & 5.8 & 9.5 & 6.9 \\
\hline
\end{tabular}

${ }^{\mathrm{X}}$ In a column means having similar letter(s) are statistically identical and those having dissimilar letter(s) differ significantly as per 0.05 level of probability 


\section{Length of spike}

Length of spike varied significantly among the dendrobium cultivars. However, longest spike was found from $\mathrm{V}_{1}(44.6 \mathrm{~cm})$ while $\mathrm{V}_{2}(32.0 \mathrm{~cm})$ had the shortest one (Table 3). Longest spike $(54.2 \mathrm{~cm})$ was found from cv. Sonia-17 (Sunil and Swati, 2013) which is the resemblance of the current study. This is in accordance with the findings of Lekha rani (2002) in Dendrobium orchids, Ninitha Nath (2003) in monopodial orchids.

\section{Girth of spike}

Significant variation was recorded from the dendrobium cultivars for girth of spikes. Maximum girth of spikes was found from $\mathrm{V}_{1}(7.4 \mathrm{~mm})$ while minimum from $\mathrm{V}_{2}(5.8 \mathrm{~mm})$ (Table 3).

Table 3. Response of dendrobium cultivars on flower characteristics ${ }^{\mathrm{X}}$

\begin{tabular}{|c|c|c|c|c|c|}
\hline Variety & $\begin{array}{l}\text { Length of } \\
\text { spike }(\mathrm{cm})\end{array}$ & $\begin{array}{l}\text { Girth of spike } \\
(\mathrm{mm})\end{array}$ & $\begin{array}{l}\text { Number of } \\
\text { floret/spike }\end{array}$ & $\begin{array}{l}\text { Diameter of bud } \\
(\mathrm{mm})\end{array}$ & $\begin{array}{c}\text { Diameter of } \\
\text { floret }(\mathrm{cm})\end{array}$ \\
\hline $\mathrm{V}_{1}$ & $44.6 \mathrm{a}$ & $7.4 \mathrm{a}$ & $12.2 \mathrm{a}$ & $26.1 \quad \mathrm{a}$ & $9.5 \mathrm{a}$ \\
\hline $\mathrm{V}_{2}$ & $32.0 \mathrm{c}$ & $5.8 \mathrm{c}$ & $9.8 \mathrm{~b}$ & $18.3 \mathrm{c}$ & $8.5 \mathrm{~b}$ \\
\hline $\mathrm{V}_{3}$ & $34.5 \mathrm{~b}$ & $6.6 \mathrm{~b}$ & $4.4 \mathrm{c}$ & $22.7 \quad b$ & $9.0 \mathrm{ab}$ \\
\hline LSD0.05 & 0.8 & 0.7 & 1.6 & 1.6 & 0.7 \\
\hline $\mathrm{CV} \%$ & 6.8 & 3.6 & 9.3 & 8.7 & 9.0 \\
\hline
\end{tabular}

${ }^{\mathrm{X}}$ In a column means having similar letter(s) are statistically identical and those having dissimilar letter(s) differ significantly as per 0.05 level of probability

\section{Number of floret/spike}

Maximum number of floret/spike was found from $\mathrm{V}_{1}$ (12.2) followed by $\mathrm{V}_{2}(9.8)$ whereas minimum from $V_{3}$ (4.4) (Table 3). Sunil and Swati (2013) found that Sonia-17 produced 11.4 number of florets/spike.

\section{Diameter of the bud}

Maximum bud diameter was found from $\mathrm{V}_{1}(26.1 \mathrm{~mm})$ followed by $\mathrm{V}_{3}(22.7 \mathrm{~mm})$ while minimum from $\mathrm{V}_{2}(18.3 \mathrm{~mm})$ (Table 3$)$.

\section{Diameter of floret}

Maximum floret diameter was found from $\mathrm{V}_{1}(9.5 \mathrm{~cm})$ which was statistically similar with $\mathrm{V}_{3}(9.0$ $\mathrm{cm})$ while minimum from $\mathrm{V}_{2}(8.5 \mathrm{~cm})($ Table 3$)$.

\section{Conclusion}

It may be concluded that growth and flowering behaviour of three tested cultivars of dendrobium varied significantly. Among these cultivars, $V_{1}$ (Sonia-17) performed best in terms of growth and flowering potentiality; thus could be further experimented for varietal selection and or improvement.

\section{References}

Ahlawat, T. R., Barad, A. V. and Jat Giriraj (2012). Evaluation of gerbera cultivars under naturally ventilated polyhouse. Indian J. of Hort. 69(4): 606-608.

Barman, D., Basak, J., Rai, B., Devadas, R., Nagarase, V. and Medhi, R. D. (2007). Performance of Cymbidium hybrids in Mid hill situation of Sikkim. J. Orn. Hort. 10(1): 30-33. 
Bhattacharjee, S. K. (1981). Studies on the performance of different varieties of Gerbera jamesonii hybrida under Bangalore condition. Lal Baugh. 26(3): 16-23.

Chen, S. C. and Tsi, Z. H. (2000). The orchards of China. 2nd Ed. The Chinese Forestry Press, Beijing, China.

Gomez, K. A. and Gomez, A. A. (1984). Statistical Procedure for Agricultural Research ( $2^{\text {nd }}$ edn.). Int. Rice Res. Inst., A Willey Int. Sci., pp. 28-192.

Islam, M. S., Mehraj, H., Roni, M. Z. K., Shahrin, S. and Jamal Uddin, A. F. M. (2013). Varietal study of Anthurium (Anthurium andraeanum) as a cut flower in Bangladesh. J. of Bangladesh Academy of Sci. 37(1): 103-107.

Lavarak, B., Lavarak, P. S., Harris, W. and Stocker, G. (2006). Dendrobium and its Relatives. Portland: Timber Press, 287p.

Leitch, I. J., Kahandawala, I., Suda, J., Hanson, L., Ingrouille, M. J., Chase, M. W. and Fay, M. F. (2009). Genome size diversity in orchids: Consequences and evolution. Ann. Bot. (Lond.) 104: 469-481.

Lekha Rani, C. (2002). Intra and interspecific hybridization in Dendrobium spp., Ph.D. Thesis Kerala Agric. Univ., Thrissur, (India).

Nair, A., Sujatha and Shiva, K. N. (2002). Genetic variability, correlation and path coefficient analysis in Gerbera. J. Orn. Hort. 6(3): 180-187.

Ninitha nath, C. (2003). Compatibility studies in monopodial orchids. M.Sc Thesis, Kerala Agric. Univ., Thrissur, (India)

Rajeevan, P. K., Kumari, P. K., Valsala, P., Rao G. S. L. H. V., Liji, P. V. and Mohan, S. (2007). Performance evaluation of cut flower varieties of anthurium under two agro climatic conditions. $J$. Ornament. Hort. 10(3): 177-180.

Ramachandrudu, K. (2008). Performance of Dendrobium orchids under agro-climatic conditions of Goa. J. of Ornament. Hort. 11(3): 232-234.

Roychowdhury, N., Mandal, T., Munsi, P. S. (2004). Evaluation of different Dendrobium spp. under polyhouse in North-East Indian hills. Acta Hort. 658: 315.

Shaukat, S., Shah, S., Shaukat, S. and Shoukat, S. (2013). Performance of gladiolus (Gladiolus grandiflora L.) cultivars under the climatic conditions of Bagh Azad Jammu and Kashmir in Pakistan. J. Cen. Eur. Agriculture. 14(2): 636 - 645.

Shiragur, M., Shirol, A. M., Gorabal, K., Reddy, B. S. and Kulkarni, B.S. (2004). Evaluation of standard carnation cultivars for their flowering, flower quality and yield parameters under protected cultivation. J. Orn. Hort. 7(3-4): 206-211.

Shruti, W. and Gajbhiye, R. P. (2012). Performance of gerbera varieties for flowering, yield and quality parameters under shade net. Indian J. of Hort. 69(1): 98-100.

Singh, A. K., Singh, D. K., Singh, B., Punetha S. and Rai, D. (2013). Evaluation of carnation (Dianthus caryophyllus L.) varieties under naturally ventilated greenhouse in mid hills of Kumaon Himalaya. Afr. J. Agric. Res. 8(29): 4111-4114.

Sugapriya, S., Mathad, J. C., Patil, A. A., Hegde, R. V., Lingaraju, S. and Birdar, M. S. (2012). Evaluation of Dendrobium orchids for growth and yield grown under greenhouse. Karnataka J. Agric. Sci. 25(1): 104-107.

Sunil, K. and Swati, S. (2013). Studies on performance, genetic variability, heritability and correlation of Dendrobium orchids under agro-climatic conditions of Pasighat, Arunachal Pradesh. Int. J. of Agril. Environ. and Biotech. 6(1): 101-108.

Talia, C. M. A., Lucia, B. D. E., Cristiano, G. and Albanese, M. (1999). Dendobium phalaenopsis: Vegetative growth and flowering. Colture Protette. 28(1): 65-70. 
Thomas, B. and Lekha Rani, C. (2008). Assessment of floral characters in commercial varieties of monopodial orchids. J. Orn. Hort. 11(1): 15-20.

Wang, H. Z., Feng, S. G., Lu, J. J., Shi, N. N. and Liu, J. J. (2009). Phylogenetic study and molecular identification of 31 Dendrobium species using inter-simple sequence repeat (ISSR) markers. Sci. Hort. 122: 440-447.

\section{Citation for this article (APA Style):}

Mehraj, H., Shikha K. J., Nusrat A., Shiam I. H. \& Jamal Uddin, A. F. M. (2014). Growth and Flowering Behaviour of Dendrobium Cultivars. Journal of Bioscience and Agriculture Research 02(02), 90-95.

Retrieved December 28, 2014, from http://www.journalbinet.com/current-issue-jbar-1.html 